\title{
Liberal democracy and globalized capitalism in Africa: Perspective from Heidegger
}

\author{
Joseph Nnnemeka Agbo \\ Department of Philosophy and Religion, Ebonyi State University, Abakaliki, Nigeria. \\ Email: jeocoagbo@gmail.com; Tel: +234 803-579-8085.
}

Copyright (c) 2021 Agbo. This article remains permanently open access under the terms of the Creative Commons Attribution License 4.0, which permits unrestricted use, distribution, and reproduction in any medium, provided the original work is properly cited.

Received 21st June, 2021; Accepted 30th August, 2021

\begin{abstract}
This paper sets out to defend a set of mutually inclusive theses. First, it argues that liberal democracy's sojourn in Africa is not political but economic. Secondly, that there is nothing natural about capitalism, rather capitalism was forcefully globalized in order to create the false impression that man is by nature motivated by self-interest or profit. But this paper demonstrates the historicity of capitalism. Finally, the paper employs Martin Heidegger's ontological analysis to show that liberal democracy is just the political manifestation of what he calls "the nihilism of Western metaphysical thinking", a thinking that is expansionist, dominating and ultimately "enframing"; (controlling). Using the expository, historical, analytic and critical methods, the essay demonstrates that the liberal democratic march in Africa is to provide the enabling conditions for capitalist exploitation. Thus, it argues that without the political ground- clearing capacity of liberal democracy, the economic domination and control by capitalism in Africa would be very difficult. In conclusion, the paper draws from the actual experience of liberal democracy and the thrust of capitalism in Africa to demonstrate their ontological ambivalence.
\end{abstract}

Keywords: Capitalism, democracy, Heidegger, liberalism, nihilism, ontology.

\section{INTRODUCTION}

It is lamentable that after over 50 years of the so-called "independence" by many African countries, Africa still needs to have her elections "observed", "supervised" and even "sponsored" in order to obtain legitimacy. Bodies like the UN, the EU, DFID, the IMF, World Bank, as well as countries like the United States, Great Britain, China, Germany, France, and (even in recent times) Arab and Asian nations create so much frenzy when African countries organize one election or the other.

But can i hear someone ask, "why not?", "Why shouldn't the West or Europe be interested in elections in Africa?" After all, many of the countries in Africa were created in Berlin in 1884-5. The political system, liberal democracy, is imported from the West. Africa has been educated the Western way, Africans go out of the continent for real medical help, MacDonald is our snack shop, Michael Jackson is our music, Christianity and Islam are our religions, English, French, etc., are the languages we speak, suits and suicidal ropes (called ties) are our dresses, spaghetti and Quaker oats constitute our diet, dog-eat-dog capitalism is our economics, and, for those of us academics, who are blackmailed to "publish or perish", publishing in any foreign journal has become the best way to acquire the hallowed title of "scholar" and earn respect from colleagues (although sometimes the demand is justified to the extent that it involves peer-reviewing).

With the above state of affairs, it becomes understandable and explainable the meddlesomeness of Europe in Africa's politics. And when we realize the pivotal nature of politics in human affairs, we then see that unless Africa rescues herself from political control, the continent would remain in the stranglehold of foreign powers.

The purpose of this essay is to argue that liberalism's sojourn in Africa is not political, it is economic. In other words, Western interest in Africa's political activities is to ensure that the so-called "ennobling conditions" are created for commerce. The popular definition of politics as something that deals with "who gets what, when, how?". Laswell (1951) gives credence to the argument that economy (capitalism) defines all the interest of the 
Western world in Africa's politics.

In the course of this essay, attempts shall be made to answer the following questions and similar others:

1. Is the relationship between Liberalism and Democracy necessary? Must Democracy be Liberal Democracy? What is responsible for the continuous demand for Africa to liberal-democratize or be doomed?

2. What is the connection between Liberal Democracy and the globalization of Capitalism?

3. What, if one may ask, is the reason for the usual, unprecedented interest in elections in Africa especially by western countries? Is it love, good neighborliness, or sheer adventure? What do the so-called "foreign observers" come to do during such electioneering and elections?

4. What can we draw from Martin Heideggers' analysis of the nihilism of western metaphysical thinking that would provide explanation for the sojourn of Liberal Democracy and Capitalism in Africa as well as provide a panacea for the continent?

The fusion of the individual-oriented capitalism and democracy in much of Africa has created strange economic and political systems inimical to post-colonial Africa. The African society is being run by a few individuals who exploit and lord it over the rest in both economic and political terms. After the Second World War, modern societies had tilted toward capitalist and socialist systems. These are two economic systems which also, inexorably, determine different political options. While capitalism determines capitalist democracy or what has come to be known as liberal democracy, socialism determines socialist or the so-called people's democracy.

With the deepening of economic recession in Europe, we are sure to expect more of such Western interest in Africa's politics in the name of globalization and, of course, to further the age long global thrust for capital. Thus, liberal democracy's sojourn in Africa has the fundamental goal of creating the conducive environment for the good old capitalist exploitation. We also intend to show in this paper, that there is nothing naturally human or humanly natural about capitalism. From Karl Marx, capitalism's greatest criticizer, we see that capitalism has an inherent tendency to be expansionist. In a relatively recent reflection, Peter Hudis has noted how over a hundred and fifty years ago, Marx had pointed to the global thrust of capital. According to Hudis:

in the journalistic and academic worlds alike, a number of re-appraisals of Marx' work are appearing that identify the $19^{\text {th }}$ century thinker as "the prophet of globalization"; because of his focus on capital's inherent drive for self-expansion and technological innovation, on the one hand and its tendency to exacerbate social inequality and instability, on the other. Even some of globalization's most fervent supporters note the importance of Marx' work for anticipating the imbalances and disturbances associated with the unfettered expansion of global capital (Hudis, 2016).

Although Marx is not the focus of our analysis in this essay, Hudis view that Marx had seen this globalization of capital is absolutely correct. But beyond Marx' discovery, other interest in this paper is to use one of Western philosophy's most acknowledged thinker, Martin Heidegger, to show that liberal democracy is the driver, propeller and culmination of what Heidegger calls "the nihilism of western metaphysics". Heidegger's distain for both liberalism and its political offshoot, liberal democracy, becomes a basis, not only for understanding why capitalism and democracy go together, but also a ground upon which Africa can start to liberate her people from this state of cultural fixation.

Employing, expository, historical, analytic and critical methods, the paper demonstrates that there is nothing global about capitalism; rather, capitalism was deliberately globalized in the political exportation of the liberal democratic ethics. Without liberal democracy, capitalism would have been grounded in Europe, where violent revolutions were needed to entrench it. Paradoxically, without capitalistic incentives (such as the so-called FDIs), liberal democracy would have been hard to export to cultures outside its birthplace in the West. African leaders should pause and ask themselves whether there is a "Santa Claus" in Capitalism. Why is a Santa Claus a religious creation? If we remember Marx again, we then see that almost everyone in Africa has taken the opium and are suffering the tranquilizing and dociling effects.

\section{Concept clarifications and theoretical framework.}

This essay focuses essentially on liberal democracy (with the capital "L" and "D") and its sojourn in Africa. Liberalism despite having ideological, theoretical and political meanings, would be understood in this essay in its ontological perspective as "a set of ideas in social and political thought which emphasizes the value of individuals' rights, and individual freedom of choice and freedom from interference" (Motner, 2000: 316).

The democracy in focus in this essay is, thus the one liberalized; that is, the one that have individuals as fulcrum of reality. On its part, democracy is that ideal that grants the population or people in a particular constituency the right to decide who governs them. The democracy we are concerned with here would consequently, be conceived as political liberalism.

Several scholars have discussed and analyzed the relationship between liberalism and democracy, especially in western civilization. One of those views has it that if recourse is made to the Athenian beginning of democracy, 
Integ. J. Arts and Human.

it means that democracy preceded liberalism in the west. However, if the focus is on the modern period, then Liberalism preceded Democracy by at least 200 years. The implication of this, for our African context, is that liberal Democracy is not a universal political culture

For Parekh, therefore, "in the modern period, liberalism preceded democracy by nearly 200 years and created the world to which the latter had to adjust" (Parekh, 1993:152).

If we conceive liberalism as the upholding of the individual rights and liberties, and conceive democracy as the system of government which thrives on the people's freedom to decide how they are governed, then, liberal democracy can be conceived as that people-oriented system where the individual's rights to choose, freedom to decide and all forms of liberties are respected, protected and never restricted. This gives room for the individual in a liberal democratic system to live the sort of life that could be described as ideal. This implies references to the political, economic, social and moral dimensions of life. Little wonder John Dewey conceives liberal democracy as a social strategy for enabling individuals to live the good life (Dewey, 1988: 224-30).

Capitalism is that economic philosophy or system that enables individuals to own the means of production (instruments and objects of labour), to enable them produce goods and services (commodities), which are then sold for the sole aim of making profit.

This essay is anchored on the theoretical framework of Martin Heidegger's analysis of the nihilism of western metaphysical thinking. Heidegger argues that this thinking, which began in Plato and ended perhaps, in Hegel, is sciento-technological and thus, ultimately dominating and "enframing". It is, therefore, the contention of this essay that politics is the culminating sphere of this thinking, with liberal democracy as the grand manifestation of its dominating and controlling character.

The next section shall address the meaning, nature as well as critique of capitalism.

\section{CAPITALISM AND ITS CRITIQUE}

Inspite of its popularity and permeation, capitalism has had a lot of critics, even after its seeming triumph, following the crisis in the socialist movement as a result of the breakup of the Soviet Union and the collapse of communist regimes in Eastern Europe. Of course, one of the greatest critics of capitalism was Karl Marx. Marx's critique of capitalism is thorough going and comprehensive that he dedicated a book (in three volumes) to it, simply titled Capital (Marx, 1986). The meaning and dynamics of capitalism are replete in scholarly literature and would not so much occupy us here.

In the Communist Manifesto, Marx and Engels conceive capitalism as an oppressive system which appropriates the resources of the state by exploiting the masses to the benefit of the few who are in the same class with the ruling class (Marx and Engels, 1975). Modern academic definition sees capitalism as "an economic system in which the ownership and management of productive wealth is vested in private enterprises who hire labour and compete with one another in providing goods and services for profit" (Smith and Futcher, 1966; 53). One common index however is, capitalism is a system motivated by profit maximization and self-interest which are the products of an individualistic culture. To this end, capitalism has been honed as dependent on the Western classical economic principle that every agent is actuated by self-interest (Hahn and Hollis, 1979; 3). In this contest, "self-interest" is contrasted with "selfishness", with the latter conceived as the negative manifestation of the former, which is perceived as being essentially good in itself and natural to man.

However, if it is true that every agent in the world is actuated by self-interest, Momoh contends that no one should honestly quarrel with what the capitalist economics stand for (Momoh, 1991; 58-59). But the fact is that many do and that suggests that there is an aspect of that thesis that is not clearly stated or not stated at all. We may indicate here that even if it is psychologically tenable that every agent in the world is actuated by self-interest, it is not empirical that every agent in the world follows through with this instinct. Just like we all have the instinct to kill our enemies, but only an insignificant population of mankind satisfies this instinct in the final analysis. Therefore, having the motivation to follow through with the exploitative tendencies of capitalism does not and cannot justify the system.

If democracy is truly a government founded on the principles of liberty and equality (Fukuyama, 1992; xi.) which makes it seemingly more prosperous than its alternatives; and capitalism is the economic demonstration of these principles, why is there so much injustice in capitalist democracies? Of course, promoters of democracy as the only viable political option would argue that the defect is not due to democracy itself but to the human agent. Francis Fukuyama argues famously that:

\begin{abstract}
While earlier forms of government were characterized by grave defects and irrationalities that led to their eventual collapse, liberal democracy was arguably free from such fundamental internal contradictions. This was not to say that today's stable democracies, like the United States, France, or Switzerland, were not without injustice or serious social problems. But these problems were ones of incomplete implementation of the twin principles of liberty and equality on which modern democracy is founded, rather than of flaws in the principles themselves (Francis Fukuyama, 1992: xi).
\end{abstract}

But is the rationality usually vouched for liberal democracy a conceptual or practical fact? How does one explain the 
obvious irrationality and immorality that characterize partisan politics, especially in the emerging of candidates and voting process in Africa's chequered romance with liberal democracy? Can there really be anything like "complete implementation" of the liberal democratic ideal, especially in societies that do not give priority and primacy to atomistic individuality as liberal democracy would have us believe. Philippe Schmitter (Schmitter, 1994: 58-72) have been in the forefront of analysts who are critical of the liberalism in democracy as well as the dangers and dilemmas inherent in a strict, globalized liberal export of the option. Blaming the agents or operators of a system and exonerating the principles is impossible because the principles themselves were articulated by other agents (thinkers). There is nobody called "Democracy" outside human conception and practices.

\section{CAPITALIST DEMOCRACY IN AFRICA}

In Africa, neither capitalism nor liberal democracy has fared any better. Capitalism promotes principles such as class segregation and individualism which rival the pervading socio-economic and political order in Africa. As Chinwe Nwoye notes, the order in Igboland for example "...encourages equality, communalism and egalitarianism at all levels" (Nwoye, 2011; 304-317). These are not coveted principles in capitalism which encourages - a dogeat-dog kind of practice. Democratic practice on the other hand buoyed by its principle of majority rule is susceptible to abuse and corruption. In Africa, the Aristocratic class has seized this loophole to oppress the masses such that Aristocracies and even semi-dictatorships like those in Zimbabwe under the recently dead Robert Mugabe, Uganda under Yuweri Museveni, Nigeria under Muhammadu Buhari, now masquerade as democracies. What is needed after all is occasional sprinkling of election where voting process is manipulated to award majority figure to the in-sitting dictator and his cabals. What happened at the election petition tribunal (in, 2019), between incumbent president Muhammadu Buhari and leader of the opposition party, Atiku Abubakar, kept many wondering what democracy really means in and for Nigeria.

In the traditional Africa where consensus principle rather than the majoritarian principle characterized democratic practices, it is hard to see how such Aristocrats and Dictators and the corruption which enabled them to emerge would thrive. The practice of liberal democracy in Africa has left the masses disgruntled. Basic meanings to certain terms have been altered. The concept of "majority" for example is now understood to mean the ethnic group with numeric advantage or simply the ethnic group in power. The concept of "the people" is now interpreted in two ways at least. In practice it means the ruling cabals and in theory where class segregation is implied, it means the down trodden, the poor masses and the ruled. So, the masses are now referred to as the people in quite a different sense from those in the ruling class.

The weaknesses of liberal democracy in Africa has led to the so-called democracies evolving into autocracies where the concept of "the people" now mean according to Eskor Toyo, those that are ruled by the autocrats. Where it evolves to plutocracy, "the people" means the poor majority. In a capitalist society "the people" means everyone except the capitalists and their collaborators on top (Toyo, 2001). He goes on to observe that the concept of "the people" with two different senses emerges and makes sense only in a class divided society. Capitalist democracies as are now practiced in Africa have, to say the least, divided the African societies into rich and poor, exploiter and exploited, privileged and underprivileged, powerful and powerless, and ruler and ruled with different and often opposed interests (Toyo, 2001). Perhaps, the most troubling effect of liberal democracy in Africa is that every section of the society has some serious worries. The aristocrats, plutocrats, dictators and the autocrats are threatened by the number of poor masses. The tribes feel threatened by one another. The minority ethnic groups are afraid of the majority ethnic groups. Niger Delta Region, which provides the economic mainstay of Nigeria should not be branded a "minority" simply because of population and land mass. Consequently, I had called for a real definition of the concept of the majority-minority imbroglio in other to place the Niger Delta Region where it belongs; a super economic majority.

Further in this mistrust, by the democratic system in Africa, the individual is abused by the state and the state is suspicious of the individual. (Mahmood Mamdani (1998; 74) recaps this when he observes that the majority (in terms of number or power) is afraid of justice while the minority (in terms of number or power) is afraid of democracy in Africa. This is because, whereas a just society with functional institutions would bring down the power and autocracy of the majority with which they lord over the rest, capitalist democracy in its evolutions in Africa promotes and enhances injustice, marginalization and class segregation.

In a recent reflection from the background of Chinweizu's, The West and the Rest of Us, Agbo (2015: 219-39) has noted that more than 40 years after Chinweizu penned down those thoughts, Africa has gone from bad to worse in the way she has continued to appropriate ontologically ambivalent values from the West (and even Asia) in an attempt to develop. The argument is made that the solution to this ontological disconnect would have to be politically conceived, expressed and executed. For it is the same Western countries, that began slave trade that also inaugurated colonialism. And when colonialism was no longer "fashionable", they "gave" Africa Independence(?), began sponsoring military coups against some uncompromising post-independent leaders in Africa (such as Nkurmah and Murtala Mohammed) only to discover that the instabilities engendered by constant coups and 
counter-coups, would endanger their capitalistic interest. Consequently, the new song became "liberal democratize or face doom's day". Yet, the Monarchy in Saudi-Arabia, sitting on enormous crude oil wealth, is not given the same "directive" because the system protects Western interests."

In Africa, therefore, liberal democracy is a political device for the propagation and self sustenance of capitalism. And since they both have the same ontological root, it would seem inconceivable, in western thinking, to have one without the other. But because they are aware that there are other variants of democracy, the locution "liberal democracy" is always projected, since the idea of a "liberal capitalism" would simply be a tautology.

The argument is that capitalism (that is, economy) is at the heart of the global onslaught of democracy (politics), especially in Africa. The best (perhaps, only) way to create the conditions that would be favourable for capitalist exploitation, is to gain political control through some sort of evangelistic sermonizing about the values (sometimes inevitability) of liberal democracy. Harold Laswell's popular definition of politics, as dealing with who gets what, where, and when (1951) lends strong credence to our argument. For even when the "what" refers to political positions, the positions are shared in order to give their holders access to economic control and power.

\section{REMEMBER LIBYA}

When we consider the fact that Western liberal democratic states, especially United States and Britain, are not asking Saudi Arabia to "liberal-democratize", we then see that what is upper most is the economic interest-since the Saudi Monarchy preserves and protects Western interest. Contrast that with the mayhem within the Mahgreb in 2011, beginning with the Jasmine Revolution in Tunisia and culminating in the Murder of Gaddafi in Libya, what has been described as "democratizing in excess" (Agbo and Chimakonam, 2015: 55-84). When one considers the disorder and instability in Libya, the "coup" that removed Mohammed Mossi in Egypt and similar sundry occurrences in North Africa, one sees that liberal democracy is far from being, the "final form" of human government. With Western powers scrambling for Libya's crude oil, it is no longer hidden that what happened in the country was the good old battle between capitalism and socialism, since everyone knows that the "Great Socialist Libyan Arab Jamahiriya" (as Gaddafi named the country after the 1986 US Bombing of Tripoli and Benghazi), was more socialist than capitalist before the demise of Gaddafi. To buttress the socialist tilt of Gaddafi's Libya and the capitalistic intentions of the Western invasion, in name the of democracy, let us cite this Republic Report, New York, October, 28, 2011:

New York (RR) WARSAW- Polish prime Minister Donald Tusk Blasted United States led NATO invasion of Muammar Gaddafi's Libya as hypocritical, meddling and at best as oil theftbased invasion, he said Saturday, Republic Reporters gathered... adding that NATO has given impression of invasions and military interventions using past precedents as yardstick to measure. He said NATO's pattern shows that if there is $100 \%$ chance oil wealth is involved, it sticks its head and strikes, and says it is protecting civilians. Tusk pointed at Iraq and Afghanistan as typical examples in this instance. He added, 'although there exists a need to defend civilians from a regime's brutality, is not the Libyan case yet another example of European hypocrisy in view of the way Europe has behaved towards Gaddafi in recent years or even months?' Tusk told the Gazeta Wyborcza newspaper in an interview. "That is one of the reasons for our restraint. If we want to defend people against dictators, reprisals, torture and prison, that principle must be universal and not invoked only when it is convenient, profitable or safe", 'Tusk said. Our sources pointed out Saudi Arabia, Yemen, Syria, Jordan, UA Emirate, and other Arab countries as typical example of countries affected by so- called Arab Spring, coined by Western Scholars and her League universities.

Commentators and political pundits say that Muammar Gaddafi's policies for Libyans were $100 \%$ better than western industrialized countries whose economy is crumbling in the face of distressed international market economy.... A source disclosed that western media attempts to paint Gaddafi as that evil- man but refused to tell whole story about Gaddafi. The media has successfully painted Gaddafi as a hard-core dictator, tyrant whatever you want to call him. However, the media as usual has also failed to show the kind of Gaddafi we never heard of ...

Before that western, NATO-led destruction and disruption of life in Libya, she had one of the highest GDP per capita income among the countries in Africa. The Republic newspaper report went on to give some Mind-blowing statistics of the Libya of Gadhafi, it says:

1. There is no electricity bill in Libya; electricity is free for all its citizens.

2. There is no interest on loans. Banks in Libya are state-owned and loans given to all its citizens at 0\% interest by Law.

3. Home considered a human right in LibyaGaddafi vowed that his parent would not get a house until everyone in Libya had a home. Gaddafi's father had died while he, his wife and his mother were still living in a tent.

4. All newlyweds in Libya receive \$60,000 Dinar 
(US\$5, 000) by the government to buy their first apartment so as to help start up the family.

5. Education and medical treatments are free in Libya. Before Gaddafi only 25\% of Libyans are literate. Today the Figure is $83 \%$.

6. Should Libyans want to take up farming career, they would receive farming land, a farming house, equipment, seeds and livestock to kick-start their farms- all for free.

7. If Libyans cannot find education or medical facilities they need in Libya, the government funds them to go abroad for it- not only free but they get US\$2,300/mth accommodation and car allowance.

8. In Libyan, if a Libyan buys a car, the government subsidized $50 \%$ of the price.

9. The price of petrol in Libya is $\$ 0.14$ per Liter.

10. Libya has no external debt and its reserves amount to $\$ 150$ billion- now frozen globally. Great Man-made River project in Libya... \$27 billion.

11. If a Libyan is unable to get employment after graduation, the state would pay the average salary of the profession as if he or she is employed until employment is found.

12. A portion of Libyan oil sale is credited directly to the bank accounts of all Libyan citizens.

13. A mother who gives birth to a child receives US $\$ 5,000$

14. 40 loafs of bread in Libya costs $\$ 0.15$.

15. $25 \%$ of Libyans Have University degrees.

16. Gaddafi carried out the world's largest irrigation project known as the Great manMade River Project, to make water readily available throughout the desert country.

Which other dictator has done much to his people besides. P. S. if this is the dictator he is, then give us one like him in the U.S.! (quoted in Emekesri, 2018: 166).

The report above covers core issues such as education, health, agriculture, employment and even daily needs such as the cost of fuel, electricity bread and housing.

These sound too fantastic to be true, in a world where western countries are searching for where to make an extra dollar to salvage their economies that are groaning under the weight of an economic meltdown, that has largely been brought about by the greedy and dominating character of capitalism.

According to Baspineiro (2020), there has been a drastic reduction in the order and economic prosperity that were the hallmarks of the Ghaddafi years. She argues that unlike the situation in Tunisia and Egypt, the overthrow of Ghaddafi was not led by the masses but western powers took advantage of some disquietudes within some Islamic groups in Benghazi to kill the leader of the country. She then went on to submit that:

\begin{abstract}
Nine years after his death, residents in the chaoswracked country's capital have grown to miss the longtime leader as the frustrations of daily life mount. "I hate to say it but our life was better under the previous regime," Fayza al-Naas, a 42year-old pharmacist told AFP in 2015, referring to Gaddafi's rule. A sentiment shared by many Libyans, including those who opposed him at some point. The economically and socially stable Libya under the Gaddafi versus a fragmented country, without a government, devastated by attacks, bombings, and continuous clashes, is the result of the NATO invasion in 2011. A conclusion that many regret supporting almost a decade later.
\end{abstract}

What else can some one say? This is what we get from the democracy dressed in liberal toga and a capitalism in search of markets to buy and sell commodities.

\section{HUMAN NATURE, CAPITALISM, IN AFRICA AND THE GLOBAL ECONOMIC RECESSION}

A lot has been written about the relationship between the greedy and expansionist thrust of globalised capitalism and the global economic recession of the past few years. Part of my argument in this paper is that there is nothing global about capitalism. Rather, capitalism was deliberately globalized in its attempt to find market for finished goods and raw materials and resource to produce more. Agbo (2010: 156-171) has argued (and many other analysts have done the same) that the global economic recession is nothing but a crisis given a fillip by the exploitative tendency of capitalism.

Although Arthur C. Brooks and Peter Wehner in a recently published monograph (Brooks and Wehner, 2010) have once again, like many American theorists and scholars do, tried to justify capitalism by an analysis of three models of human nature and the good old appeal to the "self- interest" (as distinct from "selfishness") argument, it is not difficult to debunk their position. If we grant their view that the model of human nature one believes in would provide the immanent metaphysical foundation for "the economic system one prefers to the political system one supports... the lives we lead, the institutions we build and the civilizations we create". But that is exactly the point at issue. Something is wrong with the model of human nature accepted by capitalism. It is not "natural," it is an "arbitrarily created" model.

The mixed model of human nature (that Man is both virtuous and vicious, noble and corrupt, reasonable and passionate), does not logically justify the creation of the capitalistic model of economy. Placing that model at the 
foundation of reality and building everything on it is both conceptually illogical and practically contentious. It is the reason behind all the crises that have bedeviled the capitalist mode of production. In his essay, "The crisis and the crises of global capitalism: Challenges for and alternatives from the South" (Keet, 2009), Dot Keet discusses the problems (and challenges) which the countries in the Southern hemisphere face from the countries in the North, since the core of the crisis come from the latter, with serious impact on the periphery (the former). He notes that majority of those who discuss the crises in the global economy do not see it as a mere financial or productive crisis, but the crisis of capitalism as such. He cites examples from analysts with the view that "the financial crisis is only the visible teeth of the structural crisis of globalized capitalism" (Mamdou Habashi), the crisis is a combination of various crisis which are all the fruits of "capitalist logic" (Francois Houtart) and that "the current crisis is neither a financial crisis nor the sum of multiple systemic crisis, but the crisis of imperialist late capitalism of generalized and financialized oligopolies" (Samir Amin) (Keet, 2009:1).

If, therefore, there is a drastic and desperate thrust into the periphery of the South, especially in Africa, it is simply in keeping with the nature of capitalist logic. And only democracy can provide both the detour and the condition for such expansionist tendency. Unfortunately for Africa, the other regions in the South, such as Asia and Latin America, have learned how to navigate through and cushion the negative effects of the upsurge in the tides of globalized capitalism, by drawing from their culture (ontological) backgrounds. They have done this through visionary and focused leadership (Agbo, 2010: 156-171). That Africa is in a neo-colonial situation is no longer an issue, the question is whether Africa is indeed independent, economically, something that the mostoptimistic of African researchers would find hard to answer in the affirmative. With Multi-National Corporations (MNCs) swarming all over Africa like bees, entrenching themselves almost with bravado, leaders in Africa are left gasping for breath and groping in the dark as they beggarly prepare grounds for the so-called Foreign Direct Investments (FDIs) as they equally dance to the tunes of polices from the bodies under the control of governments from the North- such as the IMF, World Bank and the World Trade Organization (WTO). Dot Keet paints the picture thus:

The expansionary and imperialistic nature of capitalism continues in both the political/military and economic/social (and cultural) dimensions... The financial corporations are now considered 'too big to fail', and feel they are too big to be controlled or even regulated by governments. The conglomerates are being combined, willingly or forcibly, through cannibalistic mergers and acquisitions (M\&As) in each and every sector.
The overwhelming financial, economic, political, ideological, social and cultural power exercised by such gargantuan financial and other economic entities/agencies is creating an unprecedented oligopolistic concentration of power over, and overriding, the formal processes and institutions of political 'democracy', even where they exist. (Keet, 2009:6).

The implication of this is that we are held spellbound tacitly, surreptitiously or forcibly (depending on which is necessary for control of a particular country) by the global economic structures and liberal democracy is only an instrument for this expansionist imperialism. An inevitable, inseparable and necessary relationship between liberal democracy and development is formed, fostered and forced down the mental throat of African leaders that make these leaders organize one laughable type of election after another, in order to create the false impression that "Africa is liberal democratic". We are thus faced, at this historical epoch, with what Keet calls "a crucial need for social equality and justice, and a survival necessity for humanity and the planet" (Keet, 2009:8). Technological innovation and industrial production, which are hallmarks of capitalist expansion, have resulted in so much toxic waste, to the extent that even the very survival of our planet had become a critical issue of concern for biological humanity. Of course, when a phenomenon grips the world negatively, Africa suffers its consequences more than other climes. Or have we forgotten the environmental effects of used vehicles and other toxic wastes dumped in the continent? The opening of the information space has now ensured that there are no more secrete, there are only confidential matters, which would be made open one day. Capitalism is the main focus of the democracy dressed in liberal toga. Capitalism, anchored on the moral principle of self-interest or egoism, is given an ontological primacy and falsely conceived as being the best defining element of human nature. But, Alan Lougheed (1999), while concluding his essay on the 10 years of economic liberalism (following the break-up of the Soviet Union) says that economic liberalism evidently makes "the rich get richer, the poor miss out in terms of both individuals and countries. Capital grows fatter while labour becomes learner and there is no mechanism for redistribution of income from rich to poor..." Is it any wonder that all over Africa, the practice of liberal democracy has become the most lucrative business in the continent? Political leaders, nay rulers, are falling headover-heels, to attract Foreign Direct Investments (FDIs) since it is one of the fastest ways to appropriate foreign cash with which they enhance their lives and those of their families, leaving the rest of the population to suffer in abject poverty and squalor. Public corporations are allowed to decay and then, it is bought by the same rulers, with the wealth they have stolen from the state, in the name of "privatization". 


\section{IS THE HUMAN BEING NATURALLY CAPITALISTIC?}

We must pause to ask ourselves if this gain or profit motive promoted by capitalism and given ontological (even biological) priority is a defining characteristic of man as a polis animal. Or did capitalism emerge in the historical evolution of man? If there is anything that drives the global thrust of liberal democracy, it is the economic interest, the search for markets in other to both sell finished products and services as well as to obtain raw materials for the production of more goods. Those who disagree with Marxists economic determinism may do so for its sweeping character, but certainly not because it is incorrect. Marx may have faltered in the articulation of viable alternatives to capitalism but certainly not in the description of the ethical implications and the historicism implicit in the gain motive. This point is made because it would help us not only to explain but equally understand why capitalism is pushed and thrusted towards Africa like hot knife through butter. For if it can be demonstrated that capitalism is not natural to the human specie, then it becomes easier to defend our position that it is alien to of, Africa the birth place of Homo sapiens. And who else would buttress our point more poignantly than Lord Keynes himself, as quoted by Heilborner (1964: 14), who said:

\begin{abstract}
A man who thinks that economics is only a matter for professors forgets that this is the science that has sent men to the barricades... Practical men who believe themselves to be quite exempt from any intellectual influence are usually the slaves of some defunct economist. Madmen in authority, who hear voices in the air, are distilling their frenzy from some academic scribbler of a few years back.
\end{abstract}

The movement from political philosophy to political economy was obviously a modern one. It coincided with the emergence of the liberal ontological perspective to reality, with individuals at the core of that perception (conception). A lot has been said about the importance of the rational, scientific outlook on the road to the enthronement of secular humanism. But why did the emerging bourgeoisie class require a violent revolution to enable it bring about a change in the medieval, monarchical outlook? The answer is simple: only a political change can force the economic alteration that the capitalist class so desperately needed. That equally explains why force was required to inaugurate slavery and perpetuate the colonialism that disrupted Africa's serene and structured traditional societies. The fact that capitalism had to bend over backwards in order to appropriate socialist principles to enable it survive is a pointer that it cannot be what defines human nature (Agbo, 2012).

Those who flaunt the phenomenon of "gain" or the "profit motive" as fundamental basis of human nature, and as the justification for the globalization of the capitalist mode of production, are perhaps not students of man's history. In his interesting and lucid book, The Worldly Philosophers, Heilboner notes and shows convincingly that the gain motive was "one major difference between the strange world of the tenth to sixteenth centuries and the world that began a century or two before Adam Smith, to resemble our own (Heilborner, 1964: 22). Heilborner argues that the capitalistic tilt was provided in the seventeenth and eighteenth centuries coinciding with the period of modernity. For the creation of what is called the "market system" as distinct from the then "market for exchange" of goods that existed in earlier centuries was responsible for this drastic change. The "market system" thus created "a mechanism for sustaining states and maintaining an entire society" (Heilborner, 1964: 24). He, therefore states the kernel of his explanation in the following words:

The concept of widespread gain was blasphemous enough, as we have seen. The broader notion that a general struggle for gain might actually bind together a community would have been hailed as little short of madness. There was a reason for this blindness. The middle Ages, the Renaissance, the Reformation-indeed the whole world until the sixteenth or seventeenth centuries could not envisage the market system for the thoroughly sound reason that Land, Labour, and Capital- the basic agents of production which the market system allocates-did not yet exist. Land, Labour, and capital in the sense of soil, human beings, and tools are of course consistent with society itself. But the idea of abstract land or abstract labour did not immediately suggest itself to the human mind, any more than did the idea of abstract energy or matter. Land, Labour, and capital as "agent" of production, as impersonal, dehumanized economic entities, are as much modern conceptions as the calculus (Heilborner, 1964,2425).

The implication of the foregoing is that capitalism had a historical emergence. It is not a defining characteristic of Man Qua man. There is, therefore, no logic that could plausibly argue for the impossibility of it being swept aside by the same objective tides of history, either in the nearest or farthest future. Besides, one can argue that the fact that there is a preponderance of agreement on the truth that African societies are communalistic lends credence to the view that Africa is the original habitat of the human species. If capitalism is not much more rejected by the continent that it is alien to, where else would it be? The chicken, as it were, is only coming home to roost.

In the section that follows we will discuss the perspective of Martian Heidegger and its connection to the global thrust of capitalist democracy. We have taken much time to 
present and discuss the issues because what our work wants to do is to use his analysis of the metaphysical history of western civilization and western intellectual tradition as both an explanation and panacea for the situation of liberal democracy and capitalism in Africa.

\section{THE HEIDEGGER PERSPECTIVES}

If we decide to suspend any attempt to do a critique of Heidegger's critique of metaphysics and follow his argument to a logical conclusion, two things become obvious: one Heidegger could not have been a liberal democrat, two, liberal democracy becomes the political manifestation in our day and the culmination of what Heidegger calls "the nihilism of metaphysics". Although Heidegger did not claim that his philosophy is basically a "political" one, it is obvious to any slightly deep reader that his philosophy has lots of political implications. By seeing western philosophy as basically a metaphysical continuum, which began from Plato and ends in perhaps Hegel, Heidegger's perspective on the scientotechnological result of that tradition is basically political. However, although the Heideggerian Philosophy has lots of political implications, the fact remains that it is philosophy, first and foremost. Thus, in discussing and focusing on that political interest, we cannot forget the fundamental grounding usually provided by philosophical analysis.

If Heidegger would not be called, in the strict sense, a "political philosopher", it cannot be gainsaid that not only does his philosophy have political implication, he certainly was, like all philosophers, motivated and influenced by some of the political ereignis (events) of his epoch. In the very opening page of his work, An Introduction to Metaphysics, Heidegger (1959: 1) speaks like a political revolutionary when he said that his task was to demolish a world that has grown old and to build it anew. Heidegger's seeming backward- revolution involves a return to the preSocratic experience of beings in Being; that is, an unmediated experience of beings in their phenomenality. For Heidegger, this was the situation before the beginning of being's oblivion in the philosophies of Plato and Aristotle.

The interest here is to show that the long history of Being's Oblivion had its culmination in politics and that liberal democracy is the current driver of that political philosophy (metaphysics). For as he puts it "philosophy is the theoretical conceptual interpretation of being, of being's structure and its possibilities. Philosophy is ontological" (Heidegger, 1975: 10). The history of ontology thus, becomes the history of Being's nihilism (forgetfulness) in the metaphysical philosophies from Plato to the modern period.

That metaphysical thinking shaped the structure of today's western societies and that thinking is scientific, calculative and mathematical. It presents a picture of inevitability, universality, validity and unshakability of western-based knowledge claims. Is it any wonder then that western metaphysical, epistemological, moral, political, educational, economic, and cultural positions are packaged and presented globally as the final possibilities? Would it, therefore, surprise anyone that liberal democracy is also presented as such? As a result of colonialism and its imperialistic cleavages contemporary, Africa has been force-marched and hood winked into the neo-liberal capitalist and democratic alternatives, without a consideration for the history and ontological constitutions of the many cultures within the continent. For a continent that does not give primacy or priority to atomistic individuality, this situation is surely an invitation to multiple crises in all dimensions of culture.

\section{LIBERAL DEMOCRACY AS AN “ENFRAMING”}

A close reading of Heidegger's, "The Question Concerning Technology" would show that what he refers to as "enframing" is exactly what liberal democracy is doing in politics, with politics itself enframing the other spheres of life. We have become so "enframed" by the instrumental understanding of liberal democracy, just the way we have become so "enframed" by the instrumental understanding of technology, that the essence, the truth behind the expansionist thrust of democracy is completely forgotten or ignored. We are so "enframed" that we have become "inflamed" by liberal democratic passions (Heidegger, 1977).

Heidegger argues that the instrumental definitions of technology as "means to an end" and as a human activity is "correct" but do not reveal the "true", the essence of technology. For him:

The essence of technology is by no means anything technological. Thus, we shall never experience our relationship to the essence of technology so long as we merely conceive and put forward the technological, put up with or evade it. Everywhere will remain unfree and chained, whether we passionately affirm or deny it, but we are delivered over to it in the worst possible way when we regard it as something neutral. For this conception of it, to which today we particularly like to do homage makes us utterly blind to the essence of technology (Heidegger,1977: 287-288).

Like technology, like democracy, the entire globe ("everywhere") has come under the "chain" of liberal democracy. The way politicians in today's world, particularly in Africa, "like to do homage" to liberal democracy, has made them completely blind to its essence. Earlier, we argued that the sojourn of liberal democracy in Africa (its essence in the continent) is to 
create the ennobling conditions, "everywhere" in Africa's nation-states for capitalist exploitation. For there is nothing essentially special, divine, or unique in the liberal variant of democracy that should make it put on the toga of an inevitable winner among other systems of societal governance.

Justified by the principal defender of the "system", the professor, propelled by the mass media and driven by expansionist exploitations, liberal democracy has exalted the ballot box above humanity. Liberal democracy becomes the new reason in history, the global ethic and the determinant of all cultural dynamics. Badiou and Zizek (2009) have observed that "the interminable twilight" which democracy in the form of parliamentary capitalism face today portrays the original platonic idea of the people conceived as power over themselves. For them democracy has acquired a fetishism that ensures that hiding behind the ballot box (conducting periodic elections) becomes a deceptive way of avoiding protest against injustice.

They argue that to be a critic of democracy today is a risky philosophical imperative. For them, it is no longer the question of whether a state is democratic or not, but rather the character and form of power wielded by the sovereign, especially when it is remembered that Hitler came to power as result of more or less free election (Badiou and Zizek 2009: 90-92). The implication is that those who celebrate democracy as an end are, as Heidegger pointed out earlier, blind to both its inner essence and its goal in Africa. Thus, it has been argued that "the common celebration of democracy as that which fosters individual liberty, may well be heading towards extinction" (Parkin-Gounelas, 2014; 223).

Technology provides an instrumental manifestation of the scientific stage of the history of being at the appearance of metaphysics as modern objectivism. And even at the instrumental level (that is, the understanding as the application of power machinery to production), technology has been very useful in the exercise of the dominating and embracing character of liberal democracy. In the recent elections in Nigeria (2019), billions of Naira was invested in procuring "card reader machines" that were quickly set aside for the manual "Incident Forms" whenever the former failed. And they failed (in fact, were deliberately not used) in many places. The process is manipulated and subverted at will. The hype, the frenzy and the lure of public office on the part of politicians and their hangers-on as well as the submerging of the citizenry into the sweeping tides of the democratic process, would not allow many to ask critical and deep-rooted questions.

If the essence of technology is "prior to and by no means a consequence of the scientific revolution" (Heidegger, 1977: 285) then it simply implies that it is a culmination' of the nihilism of the metaphysical thinking of the West.

Liberal democracy is a cliché, a chorus in the mouth of the people, with the system promising to play God. But in the process, it is playing Russian Roulette.
Our lives come under the castrating clutches of politics. As metaphysical thinking shapes the structures of modern societies, the men and women that ostensibly keep these societies in trust for the people, using the apparatus of the state and the instrumentality of government, further shape and reshape these societies, by their daily actions. Hiroshima and Nagasaki were more political feats than scientific. But for the instruction of Harry Truman, the world could have only "imagined" what an atomic bomb would be like. One of Africa's respected scholars, Abdul Kareem Bangura (2016) has recently argued that nearly all regimes in Africa are simply hybrid regimes that fall short of authoritarianism. This conclusion that came out of the statistical analysis of the state of liberal democracy in 50 African states, is the resultant effect of a democracy the invested on a people that give primacy to a communalist integrating ontology.

If liberal democracy is the latest and most-enduring expression of the metaphysical culture of the West, the implication is that democracy itself is nihilistic in the being of politics. And in that regard, what would be Heidegger's attitude to liberal democracy? Let us see how Wang Interestingly (and we think correctly) responds to this question, especially with references to the issue of Dasein as a communal being. According to wang (Wang, n.d: 8):

\begin{abstract}
With such an understanding of communal being especially that of the distinctions between the public and community, ecology and autonomy in mind, Heidegger could never be a democrat. The essence of democracy, according to Heidegger, is the rule of the public or majority (demos). For Heidegger, such "democracy" is only a form of nihilism. It starts from atomic egological "selves" but finally, with the help of a "technological" mastery and gigantism, "kills" the real individuality under the name of "publicness". Based on this understanding, Heidegger comes to the conclusion that democracy does not guarantee true individual liberty as "autonomy", but rather destroys the latter. Although Heidegger denies that he knows of anything that can replace "democracy" to "accommodate itself to our technological age", his understanding of communal being and autonomy strongly suggests that is "commune-cracy", if we can create this word for Heidegger's ideal community i.e., his social and political utopia, may be "better" than democracy.
\end{abstract}

It can be seen from the above view that anyone who is curious as to why we would want to draw implications from Heidegger's philosophy, especially for liberal democracy in Africa, would at least have his or her curiosity satisfied. That Wang sees in Heidegger a "commune-cracy" instead of democracy lends credence to my earlier view that the liberal variant of democracy would not be relevant for a 
people with communalist ontology (Agbo, 2016). Indeed the idea of the "public sphere" is, in Heidegger, the realm of the "They" where individual autonomy is lost. This is the state of inauthentic existence.

The aura of inevitability that surrounds the liberal democratic alternative, and Heidegger's view that "only a God can save us" is simply deductive. Heidegger came to this conclusion in the famous interview with Der Spigel where he appeared to have serious doubt about philosophy bringing direct changes in the affairs of the world. He believes that we cannot avoid or extricate ourselves from metaphysics that the only thing we can do about it is to demonstrate its nihilism. Thus, liberal democracy, in an attempt to determine its course, becomes itself the essential impossibility of determining the metaphysical in our age. Again, the indeterminateness of what democracy is without qualifying adjectives, such as "liberal", makes democracy a hollow concept, almost a "Nothing". Add this concern to the idea of the "Demos" (the "people") that are said to "rule" (Cratein), and then one comes face to face with democracy getting lost in the emptiness of its conception and the "publicness" of its practice.

The productionist metaphysics made manifest in capitalism and the political metaphysics obvious in the democratic march across the globe classically display (within modernity) the continuum of Being's forgetfulness that had been the hallmark of western thinking. Consequently, it is crystal clear that Heidegger's politics, whatever they are, includes "a contempt for democracy and the institutions of the liberal state". Heidegger's philosophical attempt to distance himself from this metaphysical thinking and its results in the entire gamut of western culture, comes in terms of a return to pre-Socratic thinking, the first beginning that can provide a basis for a new beginning. This Heideggerian perspective has a liberating implication for Africa. Post modernists have traced their pluralistic perspective to Heidegger and his critique of the dominating character of western metaphysical thinking. And Joseph Agbo has tried to draw the implications, for Africa, of the postmodern scientific thoughts of Thomas Kuhn and Paul Feyerabend (Agbo, 2014)

When a state is not liberally democratic, it is looked at as pariah state; especially when the political system operational in such states do not favour capitalistic investments. Where is Libya today after the West invaded her in the name of democratic freedom? Why was the overthrow of the democratically-elected government of Mohammed Mossi in Egypt not treated the same way the coup in Mali was treated? Why did liberal democracy attempt to change its own rules in Burundi, Rwanda, Congo DR and other African states where the faceless concept called "the people" was invoked to effect constitutional changes in order to perpetuate the rulership of the presidents of these countries? What is the relationship between democratic changes and the desire for order or stability? The point at issue here is not about the rightness or wrongness of the 3rd term bid of these rulers. The issue is the fact that they were also done "in the name of democracy". The implication is that democracy has no particular mode of being in Africa. "The people", who are usually taken for granted, are the ones that fight the battles (as in Burkina Faso when they chased out Blaise Campore, who has been in power since 1987), yet they are the ones that bear the brunt of the individuals (as rulers) who step into the fields they (the people) have cleared.

The attempt to appropriate the form of liberal democracy in Africa, without much attention to the content of democracy itself has become a classic manifestation of the nihilism of its being in Africa. The philosophy of African being is grossly forgotten or abandoned in the craze-maze, desire and demand to be liberally democratic. The communal base of primordial African politics has been denied in this demand. Yet, it is a fact that "African political systems have been raised and sustained on philosophical beliefs, contractions and positions; and that the case of the contemporary period in Africa may not be unconnected with the dislocation and/or disregard for philosophic foundations in the practice of "politics in Africa" (Odimegwu, 2008: 21). Liberal democracy is not an end. It is not a new ethic. That it cannot be avoided or totally denied, like the metaphysics of which it is only but a political unveiling, should not make it to acquire the status of irrevocability. For there is no one called the demos ("the people"), the people is as good as what Heidegger calls the neuter (the one).

\section{CONCLUSION}

In this essay, we have not only shown that democracy is the "software" that carries the capitalist "hardware", making the latter to veil its sinister motives; we have also demonstrated that politics is the best entry point for economics. Similarly, we have equally demonstrated that liberal democracy is the driver of this political process. Unfortunately, Africa has borne the brunt of this somewhat inevitable global process and in many of his works, Agbo has not only attempted to articulate and explore the dimensions, permeation and unfortunate effects of these processes (for Africa), but has also offered some suggestions of ways to extricate the continent from this situation.

Again, this paper has also shown that there is nothing natural about capitalism since it arose from the bourgeoisie revolutions that over threw the feudalist mode of production in the west. What this means for Africa is that both capitalism and its propeller, liberal democracy, do not have to be accepted in Africa, in their packaged sealedand-delivered-at-all-cost manner. This is because Africa's communalistic ontology does not draw a sharp line between individuality and communality, nor does it give 
ontological or existential priority or primacy to the former.

Finally, we saw how Heidegger's analysis of western metaphysical thinking provides a locus classicus for the expansionist and dominating character of liberal democracy. What this means is that democracy in Africa need not be liberal democracy before it can work. This paper has demonstrated that following the crucial and inevitable place of "politics" in human affairs, liberal democracy, with the global thrust of capitalism as its main objective, is the contemporary manifestation of that everpresent, ever-dominating, western metaphysical thinking. No wonder Heidegger says it can only be overcome not destroyed.

\section{CONFLICT OF INTERESTS}

Authors declare that they have no conflict of interests.

\section{REFERENCES}

Agbo J. N., \& Chimakonam, J. O. (2015). Democratizing in excess: A Marxist interpretation of the revolution in North Africa. Ufahamu: Journal of African Studies, xxxviii(2), 55-84.

Agbo, J. N. (2004). Democracy as reason (Geist) in history: Necessary, inevitable, irrevocable?" Ebonyi Journal of Humanities, 2(1), 61-86.

Agbo, J. N. (2010). Chatna Mishra on the global economic recession: Between India and Nigeria. A Discussion Journal of contemporary Ideas and Research, 2(2), 156-171.

Agbo, J. N. (2012). Capital on bail: Has capitalism been fair to socialism?" Paper Presented at the Biannual Conference of the Nigeria Philosophical Association (NPA), University of Abuja, October.

Agbo, J. N. (2014). The post-modern scientific thoughts of Thomas Kuhn and Paul Feyerabend: implications for Africa. Filosofia Theoretica: Journal of African Philosophy, Culture and Religions, 3(2), 9-37.

Agbo, J. N. (2015). The question of the west and the rest of us in Africa philosophy. In: Chimakonam, J. O. (ed.), Atuolu Omalu: Some unanswered questions in contemporary African philosophy University Press of America, New York. Pp. 219239.

Agbo, J. N. (2016). The ontological basis for the failure of liberal democracy in Africa: A Phenomenological Rescue. In: Agbakoba J. C. A., \& Ajah Tony, C. (eds.). Universalism, relativism and intercultural philosophy. Council for Research in Values and Philosophy, Washington D.C. Pp. 79-104.

Agbo, J. N. (2019). Against the political and moral conception of globalization. Filosofia Theoretica, 8(3), 21-40.

Badiou, A., \& Zizek, S. (2009). Philosophy in the present. Thomas, P., \& Tosceno, A. (eds.) Peter Engelmann Polity Cambridge.

Baspineiro R. (2020). Libya: Before and after Muammar Gaddafi. Retrieved 26th August 2021 from https://www.telesurenglish.net/analysis/Libya-Before-andAfter-Muammar-Gaddafi-20200115-0011.html

Brooks, C., \& Wehner, P. (2010). Human nature and capitalism wealth and justice: The morality of democratic capitalism, New York, A.E.I press.

Dewey, J. (1988). Creative democracy: The task before us. Boydston J. A. (ed.). Southern Illinois University Press, Carbondale. Pp. 224-230.
Emekesri, E. A. (2018). Biafra or Nigerian presidency: What the Ibos want. Fourth Dimension Publishers, Enugu.

Fukuyama, F. (1992). The end of history and the last man. Random House, New York.

Hahn, F., \& Hollis, M. (eds) (1979). Philosophy and economic theory. Oxford University Press, London.

Heidegger, M (1959). An Introduction to metaphysics. Ralph Manheim Yale University Press, New Haven.

Heidegger, M. (1975). The basic problems of phenomenology. Indiana University Press, Indiana.

Heidegger, M. (1977). The question concerning technology. In: Krell, D. (ed.). Basic writings of Heidegger. Harper and Row, New York.

Heilborner, R. L. (1964). The worldly philosophers. Clarion Press, New York.

Hudis, P. Marx in the mirror of globalization. Retrieved 24/3/2016 from www.britanica.com.

Keet, D. (2009). The crisis and the crises of global capitalism: Challenges for and alternatives from the South. A combination of two presentations made at the Conference in Brussels, October 28-November 1, sponsored by the Rosa Luxemburg Foundation in Cooperation with World Forum on Alternatives and the Translational Institute on "The World Crisis and Beyond: Alternatives and Transformation Paths to Overcome the Regime of Crisis Capitalism."

Laswell, H. (1951). Politics: Who gets what, when, how? The Free Press, Glasgow.

Lougheed, A. (1999). Economic liberalism, economic goals and economic policy: Towards utopia, brave new world or hell on earth. Discussion Papers in Economic, No. 257. The University of Queensland.

Mamdani, M. (1998). When does a settler become a native? Reflections on the colonial roots of citizenship in Equatorial and South Africa. Text of an Inaugural Lecture as A. C. Jordan Professor of African Studies, University of Cape Town. 13 May.

Marx, K. (1986). Capital: Critique of political economy. Fredric, E. (ed.). Chicago, Charles H. Kerr \& Company.

Marx, K., \& Engels, F. (1975). Collected works. International Publishers, New York

Momoh, C. S. (1991). Philosophy of a new past and an old future. African Philosophy Project's Publications, Auchi.

Motner, T (2000). Penguin dictionary of philosophy. London: Penguin Books, p. 316.

Nwoye, C. (2011). Igbo cultural and religious worldview: An insider's perspective. International Journal of Sociology and Anthropology, 3(9), 304-317.

Odimegwu, I. F. (2008). Philosophic foundations of politics. Lumos Nig. Ltd, Awka.

Parkin-Gounelas, R. (2014). Helping yourself to Heidegger. Gramma: Journal of Theory and Criticism, 18, 223-232.

Parekh, B, (1993). The cultural particularity of liberal democracy. In: David, H. (ed.). Prospect of democracy. California, Stanford University Press, p. 158.

Schmitter. P. C. (1994). Dangers and delimas of democracy. Journal of Democracy, 5(2), 58-72.

Smith, E. C., \& Fucher, A. J. (eds.) (1966). Dictionary of American politics. Barnes Noble, New York.

Toyo, E. (2001). Democracy. Academic Staff Union of Universities (ASUU) lecture series, Ahmadu Bello University, Zaria, 9th January.

Wang, Q. (n.d). Heidegger's dasein as a communal being. Retrieved June,10, 2015 from http://www.cuhk.edu.hk/rih/phs/events/200405_PEACE/paper s/WANGQingjie.PDF. 